\title{
Mencegah Terbentuknya Dinasti Politik Melalui Pola Rekrutmen Partai Politik (Studi Kasus Pencalonan Kepala Daerah di Solo 2020)
}

\author{
Imroatun Nika \\ Magister Hukum Fakultas Hukum Universitas Islam Indonesia Yogyakarta Indonesia \\ Jln. Cik Di Tiro No. 1 Yogyakarta Indonesia \\ imroatunnica@gmail.com
}

\begin{abstract}
So far, there has been a tendency for political parties to nominate candidates based on the wishes of the party elite, not through a democratic mechanism by considering the capabilities and integrity of the candidates promoted by political parties. The objectives to be achieved in this study are first, to determine the potential for the formation of political dynasties in the pattern of political party recruitment for the process of nominating regional chief in Solo 2020. Second, to determine the ideal political party recruitment model in preventing the formation of political dynasties in Indonesia. This research is normative juridical with a statutory approach and a concept approach. The results of this study conclude that first, the improper political recruitment process is closely correlated with the practice of forming a political dynasty as happened in the process of nominating regional chief in Solo 2020. The tendency to form a political dynasty will also have an unhealthy impact on the democracy, because check control and the balances of government needed in a democratic country are weak. In addition, this kind of process will open up more opportunities for the re-establishment of a political oligarchy. Second, in the future, an ideal political recruitment model is needed, such as the application of the civil service reform model or the compartmentalization model with an open recruitment process.
\end{abstract}

Key Words: Dynasty; party; politics; recruitment

\begin{abstract}
Abstrak
Selama ini terdapat kecenderungan pencalonan kandidat oleh partai politik berdasarkan keinginan elit partai, bukan melalui mekanisme yang demokratis dengan mempertimbangkan kemampuan dan integritas calon yang diusung oleh partai politik. Tujuan yang ingin dicapai dalam penelitian ini yaitu, pertama, untuk mengetahui potensi pembentukan dinasti politik dalam pola rekrutmen partai politik terhadap proses pencalonan kepala daerah di Solo 2020. Kedua, untuk mengetahui model rekrutmen partai politik yang ideal dalam mencegah terbentuknya dinasti politik di Indonesia. Penelitian ini bersifat yuridis normatif dengan pendekatan perundang-undangan dan pendekatan konsep. Hasil penelitian ini menyimpulkan bahwa, pertama, proses rekrutmen politik yang tidak baik berkorelasi erat dengan praktik pembentukan dinasti politik sebagaimana terjadi pada proses pencalonan kepala daerah di Solo 2020. Kecenderungan untuk membentuk dinasti politik juga akan membawa dampak yang tidak sehat bagi demokrasi, karena kontrol check and balances pemerintahan yang diperlukan dalam negara demokrasi menjadi lemah. Selain itu, proses semacam ini akan semakin membuka peluang untuk kembali terbentuknya oligarki politik. Kedua, ke depan, diperlukan sebuah model rekrutmen politik yang ideal, seperti penerapan model civil service reform atau model compartmentalization dengan proses rekrutmen yang terbuka.
\end{abstract}

Kata-kata Kunci: Politik; partai; dinasti; rekrutmen 


\section{Pendahuluan}

Tulisan ini secara khusus mengkaji terkait dengan upaya untuk mencegah pembentukan dinasti politik melalui pola rekrutmen politik. Hal ini dikarenakan tumbuh suburnya dinasti politik tidak terlepas dari peran partai politik dalam proses rekrutmen politik. Oligarki di tubuh partai politik menyebabkan mekanisme kandidasi dan pencalonan tidak berjalan sebagaimana mestinya. Selama ini terdapat kecenderungan pencalonan kandidat oleh partai politik berdasarkan keinginan elit partai, bukan melalui mekanisme yang demokratis dengan mempertimbangkan kemampuan dan integritas calon. ${ }^{1}$ Praktik ini akan menegasikan hak setiap orang dalam berpolitik dan berdemokrasi di Indonesia.

Elit partai politik yang berkuasa bahkan cenderung mempertahankan kekuasaan politiknya dengan menempatkan keluarganya dalam jabatan penting di internai partai politik atau secara khusus memberikan rekomendasi dalam pertarungan kekuasaan politik pemilihan umum (pemilu) atau pemilihan kepala daerah (pilkada). Akibatnya kontestasi politik yang terjadi tidak mencerminkan proses pemilihan yang sesuai dengan prinsip-prinsip negara demokrasi, dimana seharusnya semua rakyat memiliki hak yang sama dalam berpolitik. Hal itu tentu membuat praktik demokrasi yang berjalan terdegradasi oleh pertarungan kelompok elit tertentu sehingga tidak menampilkan pertarungan demokrasi yang sesungguhnya.

Data yang dilansir dari Kementerian Dalam Negeri Republik Indonesia menyebutkan bahwa sebanyak 57 kepala daerah berhasil mentransfer kekuasaan dari suami kepada istri atau dari orang tua kepada anaknya. ${ }^{2}$ Keberhasilan para kepala daerah dalam mentransfer kekuasaan kepada istri, anak, adik, ipar, atau bahkan menantunya merupakan strategi baru dalam mempertahankan dan melestarikan kekuasaan keluarga dalam pengelolaan pemerintahan, baik tingkat daerah atau nasional di Indonesia. Tentu hal ini merupakan praktik yang tumbuh subur setelah era reformasi dan hadir ditengah celah-celah demokrasi, khususnya praktik demokrasi prosedural melalui pesta politik pemilu dan pilkada.

Model pewarisan jabatan ini menyebar luas di berbagai daerah pasca kebijakan politik desentralisasi, yakni sejak adanya pelimpahan wewenang pada badan-badan dan golongan-golongan dalam masyarakat dalam daerah tertentu untuk mengurus rumah tangganya sendiri. ${ }^{3}$ Inti dari desentralisasi ini terdapat

\footnotetext{
1 Martien Herna Susanti, "Dinasti Politik dalam Pilkada di Indonesia", Journal of Government and Civil Society, Vol. 1, No. 2, 2017, hlm. 112

2 Mohtar Haboddin, "Politik Keluarga dalam Pilkada Serentak", Jurnal Transformative, Vol. 3, No. 2, 2017, hlm. 2

${ }^{3}$ Fitriyah, "Partai Politik, Rekrutmen Politik, dan Pembentukan Dinasti Politik pada Pemilihan Kepala Daerah (Pilkada), Jurnal Ilmu Politik, Vol. 11, No. 1, 2020, hlm. 1-2
} 
pada otonomi daerah yang di dalamnya mengatur terkait hubungan kewenangan antara pusat dan daerah, yang berkaitan dengan pembagian urusan penyelenggaraan pemerintahan dan cara menentukan urusan rumah tangga daerah. ${ }^{4}$ Model pembagian kekuasaan ini akhirnya oleh sebagian orang dimanfaatkan sebagai ajang untuk memperebutkan kekuasaan, bahkan ketika kekuasaan itu berhasil ia dapat, kemudian muncul fenomena pewarisan kekuasaan atau yang dikenal dengan istilah dinasti politik.

Praktik dinasti politik ini mengindikasikan bahwa terdapat problem dalam proses rekrutmen politik. Filter utama untuk menjaring calon-calon dan kaderkader berkualitas yang akan diikutsertakan dalam kontestasi politik ialah menjadi tugas utama partai politik. Kajian terhadap proses rekrutmen politik menjadi penting karena jika rekrutmen tidak baik, maka juga akan berdampak tidak baik juga terhadap partai politik yang justru akan melahirkan praktik dinasti politik. Kecenderungan untuk membentuk dinasti politik juga akan membawa dampak yang tidak sehat bagi demokrasi, karena kontrol check and balances pemerintahan yang diperlukan dalam negara demokrasi menjadi lemah. Selain itu, proses semacam ini akan semakin membuka peluang untuk kembali terbentuknya oligarki politik. ${ }^{5}$

Studi ini secara khusus menyoroti proses pencalonan Gibran Rakabuming Raka dalam Pemilihan Walikota Solo 2020. Pada saat itu, pimpinan cabang Partai PDI-P telah mengusung nama yang akan diajukan dalam proses pilkada tersebut. Tetapi dalam perkembangannya, Gibran juga turut mengajukan diri lewat partai yang sama dengan cara meminta restu langsung kepada pimpinan pusat Partai PDI-P. Keputusan akhirnya, Gibran dipilih yang dipilih dan diusung sebagai calon walikota Solo oleh PDI-P. Hal ini menarik dikaji mengingat Gibran masih terafiliasi hubungan keluarga dengan Presiden aktif (Joko Widodo) yang juga diusung oleh PDI-P.

\section{Rumusan Masalah}

Berangkat dari latar belakang masalah diatas, maka rumusan masalah dalam penelitian ini adalah: pertama, apakah pola rekrutmen partai politik dalam proses pencalonan kepala daerah di Solo 2020 dapat menimbulkan potensi pembentukan dinasti politik? Kedua, bagaimana model rekrutmen partai politik yang ideal untuk mencegah terbentuknya dinasti politik di Indonesia?

\footnotetext{
${ }^{4}$ Ni'matul Huda, Hukum Pemerintahan Daerah, Nusa Media, Bandung, 2009, hlm. 65.

${ }^{5}$ Martien Herna Susanti, "Dinasti Politik..., Op. Cit., hlm. 114
} 


\section{Tujuan Penelitian}

Adapun tujuan penelitian ini yaitu: Pertama, untuk mengetahui potensi pembentukan dinasti politik dalam pola rekrutmen partai politik terhadap proses pencalonan kepala daerah di Solo 2020. Kedua, untuk mengetahui model rekrutmen partai politik yang ideal dalam mencegah terbentuknya dinasti politik di Indonesia.

\section{Metode Penelitian}

Penelitian ini merupakan penelitian hukum normatif yang mengkaji pola rekrutmen partai politik dalam hubungannya dengan pembentukan dinasti politik di Indonesia. Bahan hukum yang digunakan adalah bahan hukum primer, bahan hukum sekunder, serta bahan hukum tersier. Pendekatan yang digunakan ialah pendekatan perundang-undangan (statute approach) dan pendekatan konsep (conseptual approach). Bahan hukum tersebut kemudian dikumpulkan menggunakan studi dokumen dan studi literatur. Temuan hasil penelitian yang diperoleh dari ketiga bahan hukum tersebut dianalisis secara deskriptif kualitatif.

\section{Hasil Penelitian dan Pembahasan}

\section{Dinasti Politik dalam Negara Demokrasi}

Indonesia merupakan negara hukum sebagaimana tercantum dalam bunyi Pasal 1 ayat (3) UUD 1945. Pasal tersebut menyiratkan bahwa segala sesuatu harus dilandaskan pada aturan hukum, menjunjung tinggi prinsip-prinsip hukum, bahkan kekuasaan pemerintahan juga harus dijalankan sesuai koridor hukum. Pemerintahan yang dimaksud tidak hanya berupa kekuasaan politik dalam menjalankan tugas dan wewenang pemerintah saat mereka berkuasa, tetapi juga pada saat suksesi kepemimpinan atau pada saat proses peralihan kepemimpinan yang dilakukan melalui pemilu atau pilkada.

Proses peralihan kepemimpinan merupakan momen krusial dalam sebuah negara demokrasi. Jika terdapat hal-hal yang melanggar hukum pada saat proses peralihan kepemimpinan tersebut, maka hal itu dianggap tidak demokratis. Gagasan demokrasi menuntut bahwa dalam pelaksanaan pemerintahan, termasuk upaya suksesi kepemimpinan dalam pemerintahan harus melibatkan partisipasi publik sebanyak mungkin sebagai wujud pemerintahan yang berbasis pada kepentingan rakyat. ${ }^{6}$ Selain itu, dalam negara demokrasi pemerintah

${ }^{6}$ Ni'matul Huda, Dinamika Ketatanegaraan Indonesia dalam Putusan Mabkamah Konstitusi, FH UII Press, Yogyakarta, 2011, hlm. 16 
dituntut untuk dapat menampung aspirasi publik dan dilarang bertindak secara sewenang-wenang terhadap warga negaranya.7

Demokrasi merupakan lambang pelembagaan kebebasan berekspresi bagi setiap warga negara, termasuk dalam hal ekspresi politik. Demokrasi adalah cerminan hak kebebasan kolektif yang di dalamnya mengandung tanggung jawab dalam kerangka membentuk masa depan negara yang lebih baik, termasuk dengan cara-cara kritik. ${ }^{8}$ Dalam pengertian yang lebih partisipatif, demokrasi ini disebut sebagai konsep kekuasaan dari rakyat, oleh rakyat, dan untuk rakyat. Kekuasaan itu pada pokoknya diakui berasal dari rakyat, dan karena itu rakyatlah yang sebenarnya menentukan dan memberi arah serta yang sesungguhnya menyelenggarakan kehidupan bernegara.

Keseluruhan sistem penyelenggaraan negara itu pada dasarnya juga diperuntukkan bagi seluruh rakyat itu sendiri. Negara yang baik idealnya diselenggarakan bersama-sama dengan rakyat atau melibatkan masyarakat dalam arti seluas-luasnya. ${ }^{9}$ Hal ini berarti kemauan politik rakyatlah yang menjadi paradigma dan parameter untuk menilai dan menentukan jalannya pemerintahan. ${ }^{10}$ Dengan demikian, hal-hal yang dijalankan tidak berdasarkan kepentingan publik atau kepentingan yang hanya didasari pada kepentingan elit politik dianggap tidak sesuai dengan prinsip negara demokrasi. Elit politik ini merupakan lingkaran orang-orang yang mempunyai kekuasaan politik, termasuk kekuasaan membentuk sebuah dinasti politik

Dinasti politik dimaknai sebagai upaya penguasa untuk menempatkan keluarga, saudara dan kerabatnya pada jabatan starategis dengan tujuan untuk membangun suatu kerajaan politik dalam pemerintahan. ${ }^{11}$ Dinasti politik dipahami sebagai strategi politik untuk tetap menjaga kekuasaan dengan cara mewariskan kekuasaan kepada orang lain yang masih merupakan kalangan sanak keluarga. ${ }^{12}$ Tujuannya agar mereka yang menjadi bagian dari sistem dinasti ini akan saling menjaga agar kekuasaanya, baik eksekutif atau legislatif, menjadi lebih kekal. Menempatkan keluarga pada jabatan strategis tentu akan memudahkan penguasa untuk mengontrol dan mengendalikan semua hal yang diperlukan penguasa. ${ }^{13}$

\footnotetext{
${ }^{7}$ Miriam Budiardjo, Dasar-Dasar Ilmu Politik, Gramedia Pustaka Utama, Jakarta, 2008, hlm. 107

${ }^{8}$ Green Mind Community, Teori dan Politik. Hukum Tata Negara, Total Media, Yogyakarta, 2009, hlm. 14

${ }^{9}$ Jimly Asshiddiqie, Hukum Tata Negara dan Pilar-Pilar Demokrasi, Konstitusi Press, Jakarta, 2005, hlm. 241

${ }^{10}$ I Dewa Gede Atmadja, Teori Konstitusi dan Konsep Negara Hukum, Setara Press, Malang, 2015, hlm. 91

${ }^{11}$ Leo Agustinus, Politik Lokal dan Otonomi Daerah, Alfabeta, Bandung, 2014, hlm. 209-211

12 Wasisto Raharjo Djati, "Revivalisme Kekuatan Familisme dalam Demokrasi: Dinasti Politik di Aras Lokal”, Jurnal Sosiologi Masyarakat, Vol. 18, No. 2, 2013, hlm. 204

${ }^{13}$ Leo Agustinus, Politik Lokal..., Loc. Cit.
} 
Timbulnya kebiasaan untuk membangun dinasti politik ini disebabkan karena masih kuatnya pandangan masyarakat yang menjunjung tinggi paham kekerabatan. Pandangan ini melihat bahwa keturunan atau kerabat dari penguasa sebelumnya memiliki kecakapan yang sama dengan penguasa yang sebelumnya. ${ }^{14}$ Padahal persepsi ini secara tidak langsung justru menumbuhkan benih-benih praktik terbentuknya dinasti politik. Dalam hal ini praktik yang terjadi ialah politik kekerabatan atau praktik yang menggambarkan suatu kerajaan politik yang diisi oleh kolega-kolega penguasa agar kekuasaan tetap berada dalam lingkaran keluarga tersebut. ${ }^{15}$

Dalam konteks itu, kekuasaan dinasti politik hampir dapat dijumpai dalam setiap periode kepemimpinan presiden di Indonesia. Bahkan, munculnya dinasti politik Presiden Jokowi yang selama ini dikenal sebagai presiden yang tidak melibatkan keluarga dalam urusan politik, lambat laun tergerus citranya karena putra sulungnya maju sebagai Walikota Solo. ${ }^{16}$ Hal tersebut tergambar dalam uraian tabel berikut ini:

Tabel 1. Keluarga Presiden dalam Lingkaran Kekuasaan Politik

\begin{tabular}{cccll}
\hline No & Presiden & Tahun & \multicolumn{1}{c}{ Keluarga } & Keterangan \\
\hline 1 & Soekarno & $1945-1967$ & Megawati (Presiden ke-5) & Anak \\
2 & Soeharto & $1967-1998$ & Titiek Soeharto (DPR RI) & Anak \\
& & & Tommy Soeharto (DPR RI) & Anak \\
3 & Habibie & $1998-1999$ & - & - \\
4 & Gusdur & $1999-2001$ & Yenny Wahid (Stafsus Presiden) & Anak \\
5 & Megawati & $2001-2004$ & Puan Maharani (Menteri \& DPR RI) & Anak \\
& & & Taufik Kiemas (MPR RI) & Suami \\
6 & SBY & $2004-2014$ & Edie Baskoro (DPR RI) & Anak \\
7 & Jokowi & $2014-2024$ & Gibran Rakabuming (Walikota Solo) & Anak \\
& & & Boby Nasution (Walikota Medan) & Menantu \\
\hline
\end{tabular}

Keterangan: Data diolah oleh peneliti

Praktik pembentukan dinasti politik ini umumnya banyak dijumpai dalam kontestasi politik lokal atau daerah, baik tingkat provinsi, kabupaten, atau kota. ${ }^{17}$ Pasca terbitnya Putusan Mahkamah Konstitusi No. 33/PUU-X111/2015 sebagai pembatalan larangan politik dinasti, sejumlah calon dari kerabat petahana maju dalam Pilkada 2015 dan terus berlanjut di pilkada setelahnya. Mahkamah

14 M. Khoiriza Nasution, "Analisis Putusan Mahkamah Konstitusi No.33/PUU-XIII/2015 tentang Politik Dinasti dalam Undang-Undang No.8 Tahun 2015 tentang Pemilihan Gubernur, Bupati dan Wali Kota", Skripsi, Fakultas Hukum Universitas Islam Indonesia, Yogyakarta, 2016, hlm. 5-6

15 Mudiyati Rahmatunnisa, "Menyoal Politik Kekerabatan di Indonesia dalam Pelaksanaan Pilkada Serentak 2020", Jurnal Academia Praja, Vol. 4, No. 2, 2021, hlm. 296

${ }^{16}$ Aan Suryatwan, "Dinasti Politik pada Kepemimpinan Presiden Jokowi Akibat Kontestasi Politik Lokal Gibran-Bobby", Journal Publicuho, Vol. 3, No. 3, 2020, hlm. 290

${ }^{17}$ Mohtar Haboddin, "Politik Keluarga..., Op. Cit., hlm. 3 
berpandangan bahwa frasa 'tidak memiliki konflik kepentingan dengan petahana' bertentangan dengan konstitusi. Atas dasar itu pula pencalonan kepala daerah yang masih terafiliasi hubungan kerabat dengan para petahana ikut bermunculan. Hal tersebut tergambar dalam uraian tabel berikut ini:

Tabel 2. Dinasti Politik dalam Kekuasaan Tingkat Daerah

\begin{tabular}{|c|c|c|c|c|c|}
\hline No & $\begin{array}{l}\text { Nama } \\
\text { Pejabat }\end{array}$ & Jabatan & $\begin{array}{l}\text { Nama } \\
\text { Kerabat }\end{array}$ & Status & Jabatan \\
\hline 1 & Hasani & $\begin{array}{l}\text { Walikota } \\
\text { Pasuruan (2010- } \\
\text { 2015) }\end{array}$ & $\begin{array}{l}\text { Ismail } \\
\text { Marzuki }\end{array}$ & Anak & $\begin{array}{l}\text { DPRD Pasuruan } \\
(2010-2015)\end{array}$ \\
\hline 2 & $\begin{array}{l}\text { Agustin } \\
\text { Teras } \\
\text { Narang }\end{array}$ & $\begin{array}{l}\text { Gubernur } \\
\text { Kalteng (2010- } \\
\text { 2015) }\end{array}$ & $\begin{array}{l}\text { R. Atu } \\
\text { Narang } \\
\text { Aries M. } \\
\text { Narang }\end{array}$ & $\begin{array}{l}\text { Kakak } \\
\text { Keponakan }\end{array}$ & $\begin{array}{l}\text { DPRD Kalteng } \\
\text { (2009-2014) } \\
\text { DPRD Kalteng } \\
(2009-2014)\end{array}$ \\
\hline 3 & $\begin{array}{l}\text { Syahrul } \\
\text { Yasin Limpo }\end{array}$ & $\begin{array}{l}\text { Gubernur Sulsel } \\
(2008-2018)\end{array}$ & $\begin{array}{l}\text { Tenri } \\
\text { Olleh } \\
\text { Puricha }\end{array}$ & $\begin{array}{l}\text { Adik } \\
\text { Keponakan }\end{array}$ & $\begin{array}{l}\text { DPRD Sulsel } \\
(2009-2014) \\
\text { DPRD Sulsel } \\
(2009-2014) \\
\end{array}$ \\
\hline
\end{tabular}

Keterangan: Data diolah oleh peneliti

Meskipun dalih utamanya karena telah ada jaminan kebebasan bagi setiap masyarakat untuk dapat berpartisipasi dalam kontestasi politik, tetapi faktanya justru juga semakin banyak menghasilkan dinasti dalam sistem politik dan pemerintahan di Indonesia. Upaya penguasa meletakkan keluarga dan kerabat pada jabatan-jabatan strategis tidak lain ialah bertujuan untuk membangun sebuah kerajaan politik di dalam pemerintahan, baik nasional maupun di tingkat lokal. Upaya itu dilakukan agar mereka yang menjadi anggota politik kekerabatan dapat saling menjaga, kekal dalam kekuasaan, serta mengendalikan pemerintahan sesuai dengan keinginan keluarga tersebut. ${ }^{18}$

Pembentukan dinasti politik tidak dibenarkan keberadaannya dalam negara demokrasi. Hal itu disebabkan karena kekuasaan politik hanya dinikmati oleh segelintir orang saja, sebab semua orang mempunyai hak yang sama untuk berpolitik. Selain itu, kekuasaan politik dapat berbahaya jika proses kekuasaan itu dipertahankan secara terus menerus, apalagi hingga diwariskan kepada keluarga atau kerabatnya. Sejalan dengan pernyataan Lord Acton bahwa kekuasaan itu cenderung disalahgunakan dan kekuasaan yang absolut pasti disalahgunakan (power tends to corrupt, and absolute power tends to corrupts absolutely). ${ }^{19}$ Dalam

\footnotetext{
${ }^{18}$ Leo Agustinus, Politik Lokal..., Loc. Cit.

19 Arsyad Sanusi, "Relasi Antara Korupsi dan Kekuasaan", Jurnal Konstitusi, Vol. 6, No. 2, 2009, hlm. 83-
} 
praktik dinasti politik kekuasaan yang absolut ini juga dapat dimaknai sebagai kekuasaan yang diwariskan kepada keluarga atau kerabatnya.

\section{Praktik Rekrutmen Politik dalam Pencalonan Kepala Daerah}

Rekrutmen politik adalah seleksi pemilihan dan pengangkatan seseorang untuk melaksanakan sejumlah peranan dalam sistem politik (umum) dan pemerintahan (khusus). Singkatnya rekrutmen politik adalah cara untuk mengisi jabatan politik dan jabatan di pemerintahan. ${ }^{20}$ Fungsi rekrutmen politik sangat penting karena merupakan kelanjutan dari fungsi mencari dan mempertahankan kekuasaan. Kelangsungan hidup sistem politik akan terancam karena tidak adanya suatu struktur organisasi yang mengurusi kehidupan masyarakat. Rekrutmen politik ini merupakan bagian dari fungsi yang harus dijalankan oleh partai politik di Indonesia.

Partai politik adalah organisasi yang bersifat nasional dan dibentuk oleh sekelompok warga negara Indonesia secara sukarela atas dasar kesamaan kehendak dan cita-cita untuk memperjuangkan dan membela kepentingan politik anggota, masyarakat, bangsa dan negara, serta memelihara keutuhan Indonesia berdasarkan Pancasila dan UUD 1945.21 Sedangkan menurut pengertian umumnya, partai politik adalah sekelompok manusia yang terorganisir secara stabil dengan tujuan merebut atau mempertahankan penguasaan terhadap pemerintahan bagi pimpinan partainya dan berdasarkan penguasaan ini memberikan kepada anggota partainya kemanfaatan yang bersifat idiil maupun materiil..$^{22}$

Berdasarkan pengertian tersebut dapat dilihat bahwa unsur dari partai politik tersebut utamanya adalah adanya kepentingan berupa kekuasaan yang diperjuangkan. Partai politik dalam perkembangannya telah menjadi penyalur kepentingan kelompok yang berusaha untuk menguasai kekuasaan pemerintah serta merebut dukungan rakyat melalui persaingan dengan satu golongan atau golongan lain yang mempunyai pandangan berbeda. ${ }^{23}$ Dengan kata lain, partai politik ini mengakomodasi keinginan dari calon kepala daerah untuk mencalonkan diri dalam proses pemilihan umum.

${ }^{20}$ Muhammad Abduh Dalimunthe, "Rekrutmen Politik dan Pemilihan Umum (Suatu Studi Terhadap Pola Rekrutmen Politik Dewan Pimpinan Wilayah Partai Bulan Bintang Sumatera Utara Dalam Pemilihan Umum Legislatif DPRD Sumatera Utara Tahun 2009), Skripsi, Fakultas Ilmu Sosial dan Politik Universitas Sumatera Utara, Medan, 2009, hlm. 204

21 Pasal 1 angka 1 Undang-Undang Nomor 2 Tahun 2011 tentang Perubahan Atas Undang-Undang Nomor 2 Tahun 2008 tentang Partai Politik

22 Miriam Budiardjo, Dasar-Dasar..., Op. Cit., hlm.. 160

23 A. Rahman H.I., Sistem Politik Indonesia, Graha Ilmu, Jakarta, 2007, hlm. 102 
Fungsi partai politik tersebut meliputi:24 (i) sebagai sarana komunikasi politik, artinya partai politik sebagai sarana agregasi kepentingan yang ingin disampaikan kepada rakyat; (ii) sebagai sarana sosialisasi politik, yaitu sarana bagi proses yang melaluinya seseorang memperoleh sikap dan orientasi terhadap fenomena politik dan untuk menciptakan citra bahwa dia memperjuangkan kepentingan umum. (iii) partai politik sebagai sarana rekrutmen politik, fungsi ini berhubungan dengan perkaderan dan rekrutmen anggota legislatif maupun eksekutif; serta (iv) sebagai sarana pengatur konflik diantara perbedaan pandangan yang berbeda-beda dalam kehidupan masyarakat yang hitrogen.

Sedangkan fungsi menurut Pasal 11 UU Partai Politik ialah sebagai sarana: (i) pendidikan politik bagi anggota masyarakat luas agar menjadi warga negara Indonesia yang sadar akan hak dan kewajibannya dalam kehidupan bermasyarakat, berbangsa, dan bernegara; (ii) penciptaan iklim yang kondusif bagi persatuan dan kesatuan bangsa Indonesia untuk kesejahteraan masyarakat; (iii) penyerap, penghimpun, dan penyalur aspirasi politik masyarakat dalam merumuskan dan menetapkan kebijakan negara; (iv) partisipasi politik rakyat Indonesia; dan (v) rekrutmen politik dalam proses pengisian jabatan politik melalui mekanisme demokrasi dengan memperhatikan kesetaraan dan keadilan gender.

Berangkat dari hal di atas, perhatian utama dalam tulisan ini ialah terkait fungsi partai politik dalam melakukan rekrutmen politik. Hal ini karena partai politik memiliki peran yang sangat erat dengan potensi pembentukan dinasti politik, mengingat partai politik merupakan pintu masuk dalam kontestasi perebutan kekuasaan politik. Tulisan ini secara khusus menyoroti praktik rekrutmen politik yang dilakukan oleh fraksi Partai Demokrasi Indonesia Perjuangan atau PDI-P dalam kontestasi Pemilihan Kepala Daerah (Pilkada) di Solo 2020. Objek penelitian ini secara khusus dipilih karena dalam Pilkada tersebut terdapat isu yang cukup menarik, yakni perebutan rekomendasi partai dalam pencalonan yang dalam hal ini erat dengan kajian rekrutmen politik.

Kasus ini bermula bahwa pada awalnya Dewan Pimpinan Cabang (DPC) PDI-P menyatakan dengan solid mendukung pasangan calon Achmad Purnomo dan Teguh Prakosa (Puguh) sebagai calon Walikota dan Wakil Walikota Solo pada Pilkada 2020.25 Pernyataan tegas terhadap dukungan kepada Achmad Purnomo-Teguh Prakosa pada pemilihan Wali Kota dan Wakil Wali Kota Surakarta disampaikan langsung oleh Ketua DPC PDI-P Solo sekaligus Walikota

${ }^{24}$ Miriam Budiardjo, Dasar-Dasar Ilmu Politik..., Op. Cit., hlm. 405-409

${ }^{25}$ Irawan Wibisono, "Achmad Purnomo Setelah Tertelikung dalam Perebutan Tiket Cawali Solo”, dalam https:/ / www.jawapos.com/ features/23/07/2020/achmad-purnomo-setelab-tertelikung-dalam-perebutan-tiket-cawali-solo/, diakses pada 18 Agustus 2021 
Solo, F.X. Hadi Rudyatmo. ${ }^{26}$ DPC PDI-P Solo mengusung dan memilih Bakal Pasangan Calon Purnomo-Teguh dinilai sudah berdasarkan penjaringan dan penyaringan menggunakan Peraturan Partai PDIP Nomor 24 Tahun 2017.27

Pengurus partai DPC PDI-P Solo menilai bahwa secara etika partai, pencalonan pasangan Purnomo-Teguh telah sesuai dengan tata tertib partai terkait dengan proses rekrutmen politik. Faktor penguatnya adalah bahwa calon yang diajukan merupakan kader partai dimana DPC PDI-P Solo dinilai sebagai perwakilan partai yang memiliki kinerja terbaik dalam proses kaderisasi partai. Di samping itu, proses pencalonan pasangan itu sendiri tidak meniadakan rekam jejak dari calon tersebut dimana Achmad Purnomo tercatat sebagai Wakil Wali Kota Solo, sehingga secara elektabilitas memadai untuk diusung.

Problem kemudian muncul ketika Gibran Rakabuming Raka, yang merupakan putra sulung Presiden Joko Widodo berminat untuk mengikuti kontestasi pilkada tersebut. Gibran dikenal sebagai pengusaha yang sebelumnya tidak mempunyai jejak politik. Gibran secara resmi bergabung dan menjadi kader partai PDI-P sejak 23 September 2019, tepat setahun sebelum kontestasi Pilkada 2020 dimulai. ${ }^{28}$ Mengingat DPC PDI-P Solo tetap mengajukan Purnomo-Teguh sebagai kader senior di internal partai yang dinilai mempunyai rekam jejak politik yang mumpuni, akhirnya Gibran mengajukan diri sebagai Calon Walikota Solo melalui Dewan Pimpinan Daerah (DPD) PDI-P Jawa Tengah. ${ }^{29}$ Singkat cerita, Dewan Pimpinan Pusat PDI-P memutuskan untuk mengusung Gibran dalam pilkada tersebut. ${ }^{30}$

Praktik pencalonan dalam konteks Pilkada Solo ini menyisakan dua polemik yang mendasar. Pertama, dari segi rekrutmen politik dianggap cenderung kurang baik. Hal ini dikarenakan dalam prosesnya sempat terjadi tarik ulur dan perdebatan yang cukup panjang dalam penentuan calon. PDI-P dinilai telah melewati proses rekrutmen politik yang cukup baik (DPC PDI-P Solo), namun citra itu harus terdegradasi karena menampilkan tontonan (media massa) yang kurang elok karena faktor perebutan calon yang akan diusung. Padahal faktor

\footnotetext{
26 Tempo, "PDIP Solo Tetap Mengajukan Purnomo-Teguh”, dalam https://koran.tempo.co/read/nasional /453908/pdip-solo-tetap-mengajukan-pasangan-purnomo-teguh, diakses pada 18 Agustus 2021

27 CNN Indonesia, "PDIP Solo Solid Dukung Achmad Purnomo Maju Pilkada 2020" dalam bttps:// www.cnnindonesia.com/ nasional/20200308180812-32-481559/pdip-solo-solid-dukung-achmad-purnomo-majupilk.ada-2020, diakses pada 19 Agustus 2021

28 CNN Indonesia, "Gibran Rakabuming Remsi Gabung PDIP" dalam https://wmw.cnnindonesia.com/ nasional/20190923174107-32-433087/gibran-rakabuming-resmi-gabung-pdip, diakses pada 19 Agustus 2021

29 Dewi Nurita, “Tak Bisa Maju Walikota Solo Lewat DPC PDIP, Gibran: Lewat DPP”, dalam https:// nasional.tempo.co/ read/1262146/tak-bisa-maju-wali-kota-solo-lewat-dpc-pdip-gibran-lewat-dpp/fulle-view=ok, diakses pada 19 Agustus 2021

30 Dani Prabowo, "Sempat Enggan Terjun Politik, Kini Gibran Resmi Diusung PDI-P di Pilwakot Solo" dalam https://nasional.kompas.com/ read/2020/07/17/17500191/sempat-enggan-terjun-politik-kini-gibran-resmi-diusungpdi-p-di-pilwalkot?page=all, diakses pada 19 Agustus 2021
} 
penentunya seharusnya bukan semata-mata didasari oleh keinginan partai atau penguasa, tetapi fakor utamanya ialah sesuai dengan keinginan atau kehendak masyarakat.

Kedua, dari segi pembentukan dinasti politik. Presiden Jokowi sebelumnya lekat dengan citra yang dekat dengan masyarakat dan keluarganya jauh dari kehidupan politik. Namun, setelah kejadian itu, citranya semakin redup dan banyak pihak juga mengkhawatirkan terbentuknya dinasti politik, mengingat saat ini Jokowi masih aktif sebagai Presiden. Bahkan disaat yang bersamaan, menantu Jokowi juga ikut terlibat dalam kontestasi Pemilihan Walikota Medan. Isu ini bahkan menarik minat media asing (Nikkei Asia), yang menyebut bahwa jika kemenangan Gibran sebagai Walikota Solo dan Bobby (menantu) sebagai Walikota Medan akan membentuk poros baru dinasti politik di Indonesia. ${ }^{31}$

Praktik semacam ini merupakan gambaran bahwa rekrutmen partai politik kita masih perlu banyak perbaikan. Dalam konteks itu, modus operandi yang biasa dilakukan oleh calon dan/atau partai politik dalam konteks rekrutmen politik ialah:32 (i) ada yang secara murni berusaha mendapat rekomendasi karena posisi di parpol karena kemampuannya; (ii) ada yang berusaha membeli langsung kepada oknum pimpinan parpol untuk pencalonan dirinya; (iii) ada yang memobilisasi tokoh-tokoh masyarakat seperti kyai untuk mencari rekomendasi ke parpol; serta (iv) ada yang diam-diam mencoba mendorong parpol tertentu agar mengajukan calon tertentu (calon boneka) yang bisa dikalahkan oleh dirinya atau mendorong satu parpol untuk mengajukan calon yang lemah.

\section{Model Rekrutmen Calon oleh Partai Politik yang Ideal}

Wasisto Raharjo Djati menilai bahwa kemunculan dinasti politik dapat terindikasi dari beberapa hal berikut: (i) kegagalan fungsi partai politik lokal untuk melakukan regenerasi politik; (ii) biaya demokrasi yang tinggi menghalangi masyarakat untuk berpartisipasi dalam suksesi kekuasaan; serta (iii) perimbangan kekuasaan antar elit lokal tidak tercipta sehingga menghasilkan sentralisasi politik di kalangan elit tertentu yang berkembang menjadi dinasti. ${ }^{33}$ Dalam konteks ini, rekrutmen politik tidak berjalan baik jika masih sibuk mencari calon diluar regenerasi politiknya, rekrutmen politik tidak berjalan baik jika harus ada biaya mahal dalam pesta demokrasi, dan rekrutmen tidak berjalan baik jika

31 Shintaloka Pradita Sicca, "Pilkada 2020 di Mata Media Asing, Dinasti Politik Jokowi Jadi Sorotan" dalam https:// wmw.kompas.com/global/ read/2020/12/09/214234870/pilkada-2020-di-mata-media-asing-dinasti-politikjokowi-jadi-sorotan?page $=$ all, diakses pada 19 Agustus 2019

32 Moh. Mahfud MD, Membangun Politik Hukum, Menegakekan Konstitusi, Rajawali Pers, Jakarta, 2010, hlm.

33 Wasisto Raharjo Djati, "Revivalisme Kekuatan..., Op. Cit., hlm. 203 
penentuan calon terlalu politis berdasarkan siapa yang paling kuat menentukan kekuasaan politik.

Terkait hal ini terdapat beberapa pilihan bagi partai politik untuk menjalakan fungsinya dalam proses rekrutmen politik, yaitu: (i) model partisan, yaitu merupakan pendukung yang kuat, loyalitas tinggi terhadap partai sehingga bisa direkrut untuk menduduki jabatan strategis; (ii) model compartmentalization, merupakan proses rekrutmen yang didasarkan pada latar belakang pendidikan dan pengalaman organisasi atau kegiatan sosial politik seseorang, misalnya aktivis LSM; (iii) model immediate survival, yaitu proses rekrutmen yang dilakukan oleh otoritas pemimpin partai tanpa memperhatikan kemampuan orang-orang yang akan direkrut; serta (iv) model civil service reform, merupakan proses rekrutmen berdasarkan kemampuan seorang calon di masyarakat. ${ }^{34}$

Dalam konteks rekrutmen politik tersebut, partai politik dapat melakukan proses rekrutmen melalui proses rekrutmen terbuka atau juga melalui proses rekrutmen tertutup. Jika menggunakan rekrutmen terbuka, maka syaratnya harus menampilkan seseorang tokoh yang dapat diketahui kinerjanya secara luas oleh publik. Dalam hal ini partai politik harus menyuguhkan calon yang berkualitas untuk mendapatkan dukungan masyarakat. ${ }^{35}$ Cara ini memberikan kesempatan bagi rakyat untuk melihat dan menilai kemampuan elit politiknya. Hal ini sejalan praktik negara demokrasi, yakni dari rakyat, oleh rakyat, dan untuk rakyat.

Proses rekrutmen terbuka dapat dikatakan sebagai mekanisme rekrutmen yang demokratis, karena menampung aspirasi publik. Adapun manfaat yang diharapkan dari rekrutmen terbuka ini adalah terciptanya mekanisme yang demokratis, tingginya tingkat akuntabilitas karena rekam jejaknya dapat dinilai, terciptanya kompetisi politik yang adil atau fair, serta diharapkan dapat melahirkan sejumlah pemimpin yang demokratis dan mempunyai nilai integritas pribadi yang tinggi.

Adapun praktik rekrutmen tertutup merupakan praktik rekrutmen yang berlawanan dengan cara rekrutmen terbuka. Dalam hal ini syarat dan prosedur pencalonan tidak dapat secara bebas diketahui umum. Partai berkedudukan sebagai promotor elit yang berasal dari dalam tubuh partai itu sendiri. Cara ini menutup kemungkinan bagi anggota masyarakat untuk melihat dan menilai kemampuan elit yang ditampilkan. ${ }^{36}$ Dengan demikian cara ini kurang kompetitif karena menutup akses publik. Hal ini menyebabkan demokrasi hanya berfungsi sebagai sarana bagi elit untuk memperbaharui legitimasinya. Mekanisme

${ }^{34}$ Fadillah Putra, Partai Politik dan Kebijakan Publik: Analisis Terhadap Kongruensi Janji Politik Partai dengan Realisasi Produk Kebijakan Publik di Indonesia 1999-2003, Pustaka Pelajar, Yogyakarta, 2003, hlm. 57

35 Ibid., hlm. 77

${ }^{36}$ Ibid 
rekrutmen tertutup ini juga dapat berkontribusi dalam pembentukan dinasti politik.

Pada prinsipnya, setiap partai politik dapat menentukan sendiri proses rekrutmen mana yang akan digunakan untuk melakukan proses rekrutmen. Artinya setiap partai politik diberikan kebebasan untuk itu dan proses yang dipilihnya akan menentukan karakteristik partai politik itu sendiri. Jika ditinjau dari beberapa pilihan proses rekrutmen di atas, idealnya partai politik seharusnya dapat mengedepankan proses rekrutmen model civil service reform atau model compartmentalization dengan proses rekrutmen yang terbuka. Partai politik harus mendasari pemilihan calon pemimpin tersebut berdasarkan kapabilitas dan kemampuannya untuk diterima oleh publik. Selain kapabilitas yang mumpuni, prosesnya juga harus dilakukan secara terbuka guna menghindari kepentingankepentingan yang cenderung politis.

Selain itu, model partisan dapat saja dipertimbangkan untuk dijadikan strategi rekrutmen politik, asalkan tetap mengedepankan faktor kapabilitas yang dapat diterima oleh publik dan dilakukan melalui proses rekrutmen terbuka. Sementara penerapan model immediate survival sepertinya kurang ideal untuk diterapkan dalam negara demokrasi. Model tersebut juga memiliki kecenderungan dengan penggunaan sistem rekrutmen tertutup, yang dapat menghalangi aspirasi publik dalam mengajukan calon pemimpin yang dianggap ideal. Meskipun dalam konteks ke-Indonesiaan sistem pemilihan umum telah dibangun dengan prinsip-prinsip demokrasi, tetapi model rekrutmen tertutup dengan cara-cara oligarki masih dimungkinkan terjadi.

Oleh karenanya, prinsip demokrasi ini tidak hanya diterapkan dalam pemilihan umum tetapi juga sudah harus dimulai dari internal partai sendiri. Setiap partai politik pasti membutuhkan kader-kader yang berkualitas, karena hanya dengan kader yang demikian ia dapat menjadi partai yang mempunyai kesempatan lebih besar untuk mengembangkan diri. Dengan mempunyai kaderkader yang baik, partai tidak akan sulit menentukan pemimpinnya sendiri. Penerapan konsep ini atau konsep rekrutmen politik yang baik diharapkan dapat membuka peluang kader-kader terbaik muncul ke permukaan publik dan dapat menutup kesempatan atau celah-celah terbentuknya dinasti politik di Indonesia.

\section{Penutup}

Berdasarkan uraian tersebut dapat disimpulkan bahwa proses rekrutmen politik yang tidak baik berkorelasi erat dengan praktik pembentukan dinasti politik sebagaimana terjadi pada kasus pemilihan calon kepala daerah di Solo 2020. Kecenderungan untuk membentuk dinasti politik juga akan membawa 
dampak yang tidak sehat bagi demokrasi, karena kontrol check and balances pemerintahan yang diperlukan dalam negara demokrasi menjadi lemah. Selain itu, proses semacam ini akan semakin membuka peluang untuk kembali terbentuknya oligarki politik. Oleh karena itu, diperlukan sebuah model rekrutmen politik yang ideal, seperti penerapan model civil service reform atau model compartmentalization dengan proses rekrutmen yang terbuka.

Dalam konteks itu, mengingat rekrutmen politik dapat menjadi pintu bagi terbukanya praktik dinasti politik, maka partai-partai politik harus mendasari pemilihan calon yang akan diusung berdasarkan kapabilitas dan kemampuannya untuk diterima dengan baik oleh publik. Meskipun studi-studi sebelumnya sudah banyak membahas soal dinasti politik, namun jarang yang mendiskusikan bagaimana proses rekrutmen politik dijalankan oleh partai politik dan mengapa calon yang berasal dari keluarga tersebut yang dinominasikan, sehingga kedepan diperlukan riset-riset lanjutan terkait hal itu.

\section{Daftar Pustaka}

\section{Buku}

Agustinus, Leo., Politik Lokal dan Otonomi Daerah, Alfabeta, Bandung, 2014.

Asshiddiqie, Jimly., Hukum Tata Negara dan Pilar-Pilar Demokrasi, Konstitusi Press, Jakarta, 2005.

Atmadja, I Dewa Gede, Teori Konstitusi dan Konsep Negara Hukum, Setara Press, Malang, 2015.

Budiardjo, Miriam., Dasar-Dasar Ilmu Politik, Gramedia Pustaka Utama, Jakarta, 2008.

Community, Green Mind, Teori dan Politik Hukum Tata Negara, Total Media, Yogyakarta, 2009.

Huda, Ni'matul, Hukum Pemerintahan Daerah, Nusa Media, Bandung, 2009.

Dinamika Ketatanegaraan Indonesia dalam Putusan Mahkamah Konstitusi, FH UII Press, Yogyakarta, 2011.

H.I. A. Rahman, Sistem Politik Indonesia, Graha Ilmu, Jakarta, 2007.

Mahfud MD, Moh., Membangun Politik Hukum, Menegakkan Konstitusi, Rajawali Pers, Jakarta, 2010.

\section{Sekripsi}

M. Khoiriza Nasution, "Analisis Putusan Mahkamah Konstitusi No.33/PUUXIII/2015 tentang Politik Dinasti dalam Undang-Undang No.8 Tahun 2015 tentang Pemilihan Gubernur, Bupati dan Wali Kota", Skripsi, Fakultas Hukum Universitas Islam Indonesia, Yogyakarta, 2016.

Muhammad Abduh Dalimunthe, "Rekrutmen Politik dan Pemilihan Umum (Suatu Studi Terhadap Pola Rekrutmen Politik Dewan Pimpinan Wilayah Partai Bulan Bintang Sumatera Utara Dalam Pemilihan Umum Legislatif 
DPRD Sumatera Utara Tahun 2009), Skripsi, Fakultas Ilmu Sosial dan Politik Universitas Sumatera Utara, Medan, 2009.

\section{Jurnal}

Aan Suryatwan, "Dinasti Politik pada Kepemimpinan Presiden Jokowi Akibat Kontestasi Politik Lokal Gibran-Bobby", Journal Publicuho, Vol. 3, No. 3, 2020.

Arsyad Sanusi, “Relasi Antara Korupsi dan Kekuasaan”, Jurnal Konstitusi, Vol. 6, No. 2, 2009.

Fitriyah, "Partai Politik, Rekrutmen Politik, dan Pembentukan Dinasti Politik pada Pemilihan Kepala Daerah (Pilkada), Jurnal Ilmu Politik, Vol. 11, No. 1, 2020.

Martien Herna Susanti, "Dinasti Politik dalam Pilkada di Indonesia", Journal of Government and Civil Society, Vol. 1, No. 2, 2017.

Mohtar Haboddin, "Politik Keluarga dalam Pilkada Serentak", Jurnal Transformative, Vol. 3, No. 2, 2017.

Mudiyati Rahmatunnisa, "Menyoal Politik Kekerabatan di Indonesia dalam Pelaksanaan Pilkada Serentak 2020", Jurnal Academia Praja, Vol. 4, No. 2, 2021.

Wasisto Raharjo Djati, "Revivalisme Kekuatan Familisme dalam Demokrasi: Dinasti Politik di Aras Lokal", Jurnal Sosiologi Masyarakat, Vol. 18, No. 2, 2013.

\section{Perundang-undangan}

Undang-Undang Nomor 2 Tahun 2011 tentang Perubahan Atas Undang-Undang Nomor 2 Tahun 2008 tentang Partai Politik (Lembaran Negara Republik Indonesia Tahun 2011 Nomor 8, Tambahan Lembaran Negara Republik Indonesia Nomor 5189)

\section{Online}

Indonesia, CNN., "PDIP Solo Solid Dukung Achmad Purnomo Maju Pilkada 2020" dalam https://www.cnnindonesia.com/nasional/20200308180812-32481559/pdip-solo-solid-dukung-achmad-purnomo-maju-pilkada-2020, diakses pada 19 Agustus 2021

Indonesia, CNN., "Gibran Rakabuming Remsi Gabung PDIP" dalam https://www.cnnindonesia.com/ nasional/20190923174107-32-433087/gibranrakabuming-resmi-gabung-pdip, diakses pada 19 Agustus 2021

Nurita, Dewi., “Tak Bisa Maju Walikota Solo Lewat DPC PDIP, Gibran: Lewat DPP", dalam https://nasional.tempo.co/read/1262146/tak-bisa-maju-wali-kotasolo-lewat-dpc-pdip-gibran-lewat-dpp/fullEview=ok, diakses pada 19 Agustus 2021

Putra, Fadillah., Partai Politik dan Kebijakan Publik: Analisis Terhadap Kongruensi Janji Politik Partai dengan Realisasi Produk Kebijakan Publik di Indonesia 19992003, Pustaka Pelajar, Yogyakarta, 2003. 
Prabowo, Dani., "Sempat Enggan Terjun Politik, Kini Gibran Resmi Diusung PDIP di Pilwakot Solo" dalam https://nasional.kompas.com/read/2020/07/17 /17500191/sempat-enggan-terjun-politik-kini-gibran-resmi-diusung-pdi-p-dipilwalkot?page=all, diakses pada 19 Agustus 2021

Sicca, Shintaloka Pradita., "Pilkada 2020 di Mata Media Asing, Dinasti Politik Jokowi Jadi Sorotan" dalam https://www.kompas.com/global/read/2020/12/09/ 214234870/pilkada-2020-di-mata-media-asing-dinasti-politik-jokowi-jadisorotan? page=all, diakses pada 19 Agustus 2019

Tempo, "PDIP Solo Tetap Mengajukan Purnomo-Teguh", dalam https://koran.tempo.co/read/nasional /453908/pdip-solo-tetap-mengajukanpasangan-purnomo-teguh, diakses pada 18 Agustus 2021

Wibisono, Irawan., "Achmad Purnomo Setelah Tertelikung dalam Perebutan Tiket Cawali Solo", dalam https://www.jawapos.com/features/23/07/2020 /achmad-purnomo-setelah-tertelikung-dalam-perebutan-tiket-cawali-solo/, diakses pada 18 Agustus 2021 